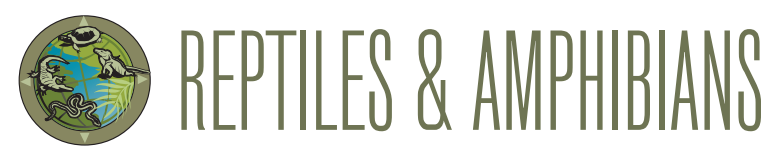

\title{
Modern-day Record of the Marbled Salamander, Ambystoma opacum (Gravenhorst 1807), from Pinellas County, Florida
}

\author{
Kenneth L. Krysko ${ }^{1}$ and Wiley G. Griste IV ${ }^{2}$
}

${ }^{1}$ Florida Museum of Natural History, Division of Herpetology, University of Florida, Gainesville, Florida 32611, USA (langaha01@yahoo.com [corresponding author]) ${ }^{2}$ Saint Petersburg, Florida, 33703, USA (wrggriste@gmail.com)

$\mathrm{T}$ The Marbled Salamander (Ambystoma opacum) is native to an area from southern Michigan and New Hampshire southward to eastern Texas and northern Florida (Fig. 1). Like many other amphibians, it has undergone population declines (Hammerson 2004). In Florida, this species is currently known to occur from the Suwannee River in the northern peninsula westward into the panhandle. Historically, this species was found in Pinellas County in the central peninsula, where two specimens (MCZ 4826-4827) were collected in Gulfport in 1918. Additionally, Bartlett and Bartlett (1999) listed two unconfirmed observations from across Tampa Bay near Lithia Springs in Hillsborough County in 1965. Herein, we document the first confirmed record of $A$. opacum from the disjunct locality in Pinellas County in 102 years.

At 2003 h on 11 April 2020, WGG observed an unfamiliar animal crawling into a stand of bromeliads at his private residence in Saint Petersburg, Pinellas County, Florida

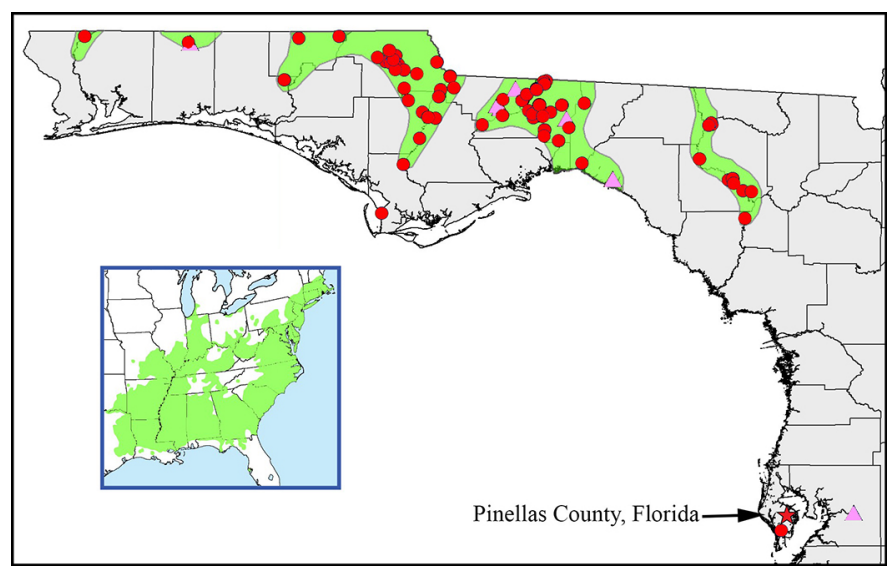

Fig. 1. Geographic distribution of the Marbled Salamander (Ambystoma opacum) in the eastern USA (inset) and Florida, modified after Powell et al. (2016) and Krysko et al. (2019), respectively. Red circles represent confirmed records, pink triangles are unconfirmed literature records, and the red star is our confirmed record.

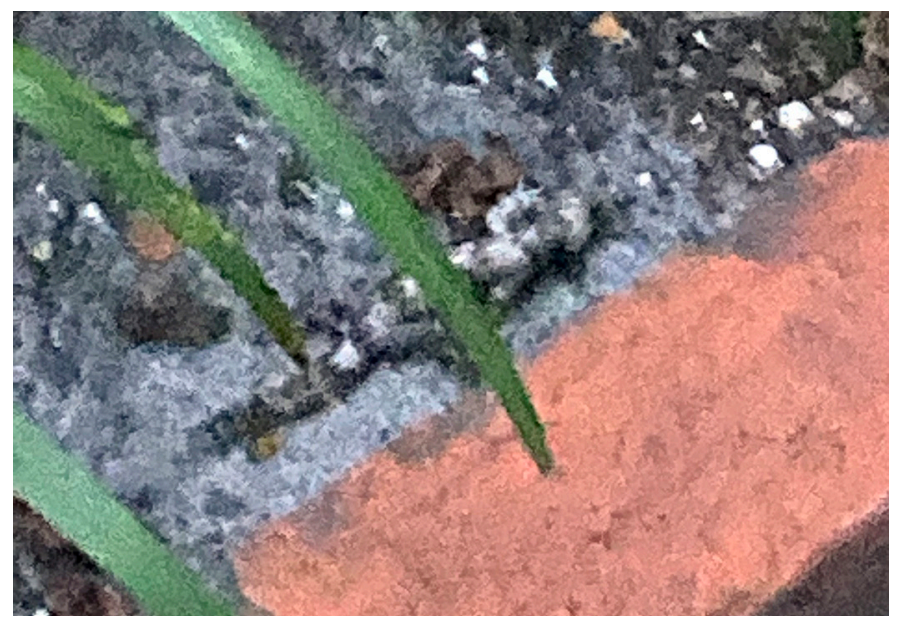

Fig. 2. A Marbled Salamander (Ambystoma opacum) observed on 11 April 2020 in Saint Petersburg, Pinellas County, Florida. Photograph taken with cell phone by Wiley G. Griste IV.

$\left(27.821002^{\circ} \mathrm{N},-82.650762^{\circ} \mathrm{W}\right)$. Although the cell-phone picture quality is poor, the animal is clearly a Marbled Salamander. The image was verified by Coleman M. Sheehy III and cataloged in the University of Florida Museum of Natural History collection as UF-Herpetology 190993.

Although we cannot rule out the possibility that this observation represents a remnant of the historically disjunct population, we believe that to be highly unlikely because of extensive development in Pinellas County, which has had the highest human population density in Florida for more than 40 years. The most likely explanation is that this individual was introduced. However, we note that Marbled Salamanders are not typical or common pets and, when WGG asked neighbors about this species, he could not find any who had kept such an animal in captivity. Furthermore, the species has never been documented as introduced in Florida (Krysko et al. 2016). Consequently, the actual explanation remains uncertain at this time. 


\section{Acknowledgments}

We thank Coleman M. Sheehy III for providing the UF-Herpetology catalog number and Louis A. Somma for helpful comments.

\section{Literature Cited}

Bartlett, R.D. and P.P. Bartlett. 1999. A Field Guide to Florida Reptiles and Amphibians (Excluding Snakes). Gulf Publishing Field Guides, Houston, Texas, USA.

Hammerson, G. 2004. Ambystoma opacum. The IUCN Red List of Threatened Species 2004: e.T59065A11864879. <https://dx.doi.org/10.2305/IUCN.UK.2004.
RSTS.T59065A11864879.en>.

Krysko, K.L., L.A. Somma, D.C. Smith, C.R. Gillette, D. Cueva, J.A. Wasilewski, K.M. Enge, S.A. Johnson, T.S. Campbell, J.R. Edwards, M.R. Rochford, R. Tompkins, J.L. Fobb, S. Mullin, C. Lechowicz, D. Hazelton, and A. Warren. 2016. New verified nonindigenous amphibians and reptiles in Florida, 1976 through 2015, with a summary of over 152 years of introductions. Reptiles \& Amphibians 23: 110-143.

Krysko, K.L., K.M. Enge, and P.E. Moler. 2019. Amphibians and Reptiles of Florida. University of Florida Press, Gainesville, Florida, USA.

Powell, R. R. Conant, and J.T. Collins. 2016. Peterson Field Guide to Reptiles and Amphibians of Eastern and Central North America. Fourth Edition. Houghton Mifflin Harcourt, New York, New York, USA. 